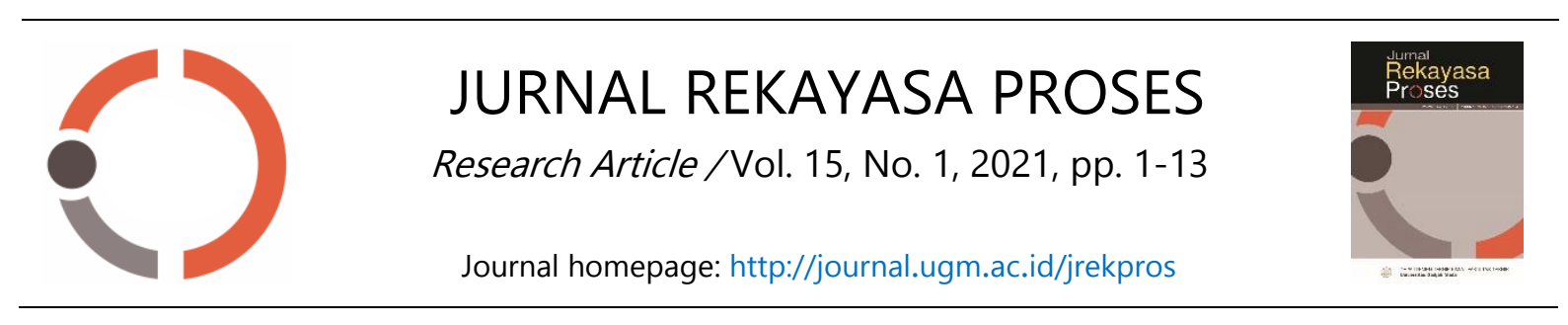

\title{
Eco-friendly Alkyd Resins Based on Vegetable Oil: Review
}

\author{
Okta Amelia ${ }^{1 *}$, Illah Sailah¹, Ika Amalia Kartika ${ }^{1}$, Ono Suparno ${ }^{1}$, Yazid Bindar² \\ ${ }^{1}$ Department of Agro-industrial Technology, IPB University, Bogor, Indonesia, 16680 \\ ${ }^{2}$ Department of Bioenergy Engineering and Chemurgy, Faculty of Industrial Technology, \\ Bandung Institute of Technology, Bandung 40116 \\ *Corresponding author: ameliao40@yahoo.com
}

(Submission: 17 February 2021; Revision: 21 May 2021; Acceptance: 31 May 2021)

\section{A B S T R A C T}

The alkyd resin industry currently needs environmentally friendly raw materials, which emphasized the aspect of sustainability. Alkyd resin is a polymer product with oil as raw material which is widely used in the paint, coating, and other industries. The abundant demand for alkyd resin has led to a diversification of the raw material for alkyd resin from vegetable oils. The advantages of vegetable oil include being a renewable energy source for industry, sustainability, biodegradability, and being environmentally friendly as important considerations for the industry in recent times. This paper examines alkyd resins derived from several vegetable oils that are environmentally friendly. Alkyd resin is prepared by alcoholysis and esterification. Based on several studies of alkyd resins, there have been many modifications to the raw materials, technology, and catalysts used which can refer to an environmentally friendly and affordable industry.

Keywords: alkyd resin; biodegradability; environmentally friendly; sustainability; vegetable oil

\section{ABSTRAK}

Industri polimer pada masa ini membutuhkan bahan baku yang ramah lingkungan, yang menekankan pada keberlanjutan. Alkid resin adalah salah satu produk berbasis minyak yang banyak digunakan dalam industri cat, coating, dan industri lainnya. Keberlanjutan, biodegradabilitas, dan keramahan terhadap lingkungan menjadi pertimbangan signifikan bagi industri berbasis minyak nabati dalam beberapa waktu terakhir. Di dalam naskah ini, diulas beberapa minyak nabati yang digunakan untuk memproduksi alkid resin dengan cara alkoholisis dan esterifikasi. Berdasarkan berbagai studi yang telah dilakukan, masih terdapat modifikasi dari sisi material, teknologi dan katalis agar tercipta industri yang ramah lingkungan.

Kata kunci: alkid resin; biodegradabilitas; keberlanjutan; minyak nabati; ramah lingkungan 


\section{Introduction}

Based on Indonesian Government Regulations Law Number 3 of 2014 concerning green industry policies, industries are required to apply sustainability aspects. The polymer industry is one of the industries that still use synthetic raw materials in its application. Polymers obtained from renewable energy come from sources such as starch, lignin, cellulose protein, chitosan, polyhydroxyalkanoate, furanone, alginate, wool, fibre, and vegetable oils. Industries that apply them include plasticizers industry, biodiesel industry, lubricants industry, and packaging industry (Salimon et al. 2012; Xia dan Larock 2010; Alam et al. 2014).

Alkyd resin is widely used in paint, coating, and lubricant industries. Currently, alkyd resin is being developed using vegetable oil as raw materials to enhance its renewability, sustainability, and biodegradability because eco-friendly products have been a particular concern for consumers in recent times. This development has given rise to several studies on the quality of oil produced from seeds (Alam et al. 2014; Uzoh and Nwabanne 2016). Polymer researchers have been using vegetable oil such as linseed oil, jatropha seeds, sunflower seeds, soybeans, and neem seed to produce alkyd resin (Chiplunkar and Pratap, 2016; Anya et al., 2016; Godfrey et al., 2019; Elba et al., 2018; Kildiran et al., 1996).

Alkyd resins have many applications in the coating industry due to their low cost, wide range of functions, and are produced from renewable vegetable oils (Soucek and Salata, 2014). Alkyd resins are a large group of thermoplastic resins which are polyester products formed from the polymeric condensation of polyhydric alcohols, polybasic acids, and monobasic fatty acids.
These components are the main raw materials used in coating formulations. Although other surface coating materials such as latex resins and powder coatings have recently been discovered, alkyd resins remain a mainstay for several applications due to their balance of economy and efficiency. Alkyd resins contribute about $70 \%$ to conventional binders used in the coating industry contributing to coating, adhesion, durability, and gloss. As coating, alkyd resins have favorable properties in terms of film hardness, gloss, durability and gloss retention, resistance to abrasion which is based on oil drying properties (Aigbodion and Okieimen, 2001).

Mutar and Hassan (2017) stated that alkyd resins have high economic value, biodegradability, durability, and flexibility. They also have abundant availability of raw materials, good adhesion, and ease of application. Alkyd resins are widely used in the paint,. The need for alkyd resin in paint industries increased from 589,604 kg in 2014 to $591,654 \mathrm{~kg}$ in 2016 (BPS, 2015).

Based on the description above, in general, vegetable oil has the potential to be converted into alkyd resin, but it is necessary to study the potential of each raw material. The raw materials used in the manufacture of alkyd resins are also used as food raw materials, so it is necessary to look for other plant alternatives that do not compete with the need of food industries.

This article summarizes the raw materials and technology used in alkyd resin production from vegetable oils. This is intended to minimize the production cost of alkyd resins and increase their economic value. 


\section{Alkyd Resin Raw Material}

Alkyd resin production using vegetable oil as raw material results in a product that matches its utilization. Alkyd resins are divided into 3 types, namely Long Oil Alkyd (LOA) containing 56\% fatty acids, Medium Oil Alkyd (MOA) containing 46-55\% fatty acids, and Short Oil Alkyd (SOA) containing less than $35-45 \%$ fatty acids (Ploeger and Chiantore, 2012). Table 1 shows the process of making alkyd resin from different raw materials.

\subsection{Alkyd Resin from Linseed Oil}

Linseed oil is produced from the hemp plant and belongs to the drying oil group. Linseed oil is often used in the coating industry to increase flexibility and speed up varnish drying (Sutanti et al., 2013). Linseed oil contains a lot of linoleic acids which has properties of unsaturated acid and cannot be reacted with acids unless preceded by alcoholysis first (Wibowo, 2013).

Işeri-Çağlar et al. (2014) investigated alkyd resins from linseed oil. Alkyd resin from linseed was synthesized by reacting the oil with trimethylolpropane and phthalic anhydride at $200-250^{\circ} \mathrm{C}$ for 12 hours. Hemp oil-based alkyd resins were synthesized in 2 stages, namely alcoholysis and esterification. Trimethylolpropane was reacted with calcium carbonate as a catalyst, added to linseed oil, then heated to $240^{\circ} \mathrm{C}$ in the alcoholysis stage and cooled to $140^{\circ} \mathrm{C}$ by adding $30,11 \mathrm{~g}$ or 0.2 mol of xylene phthalic anhydride. The esterification stage was continued by heating at $240^{\circ} \mathrm{C}$ and the reaction was maintained until the acid number decreased to $15 \mathrm{mg}$ $\mathrm{KOH} / \mathrm{g}$ oil. The results showed that drying time increased with increasing oil content in the alkyd resin. This because higher oil content lead to a lower polymerization rate of the alkyd resin.

Studies of alkyd resins with linseed oil have also been carried out by Godfrey et al. (2019). In the initial stage, the oil was reacted with glycerol at a temperature range of $230-250^{\circ} \mathrm{C}$ using lead oxide as a catalyst. The temperature was lowered when the monoglyceride mixture dissolved in anhydrous methanol at a ratio of $1: 3$ and a temperature of $180^{\circ} \mathrm{C}$. In the second stage, phthalic anhydride and xylene (as a solvent) were put into the flask and the temperature was increased to $230-250^{\circ} \mathrm{C}$. The process was monitored periodically until the acid value got below $10 \mathrm{mg} \mathrm{KOH} \mathrm{/} \mathrm{g}$ then nitrogen was introduced at this stage. The results showed that the colour of linseed alkyd resin was light yellow with an acid number of $1 \mathrm{mg} \mathrm{KOH} / \mathrm{g}$, free fatty acids content of $0.503 \mathrm{mg} \mathrm{KOH} / \mathrm{g}$, a saponification number of $194 \mathrm{mg} \mathrm{KOH} \mathrm{/} \mathrm{g,}$ a drying time of 144 minutes, and an intrinsic viscosity of 0.0442 [ $\eta$ ]. Based on these results, it can be concluded that linseed oil is potential to be made into alkyd resins.

\subsection{Alkyd Resin from Soybean Oil}

Soybean oil contains about $85 \%$ unsaturated fatty acids and about 15\% saturated fatty acids, so it is an edible oil that can be consumed directly like olive oil. Soybean oil contains linoleic acid (50\%), oleic acid (29\%), and linolenic acid (8\%). Soybean oil is generally used in the food industry but can also be used in candle, soap, varnish, and paint industries (Winarsi, 2010). 
Table 1. Alkyd resin from vegetable oil

\begin{tabular}{|c|c|c|c|c|c|c|c|c|}
\hline \multicolumn{9}{|c|}{ Alkyd resin raw material } \\
\hline Raw Material & Linsee & d Oil & Soybean Oil & & Rubber S & eed Oil & Sunflower & Seed Oil \\
\hline \multirow{10}{*}{ Composition } & Linolonic 57\% & & & & oil length of $35 \%$ & methyl ester & & \\
\hline & 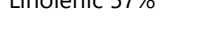 & - & - & - & for short alkyd & rubber seed oil & FFA $65 \%$ & - \\
\hline & & & & & $50 \%$ for medium & & & \\
\hline & Olexc 19\% & - & - & - & alkyd & - & Triglyceride $15.5 \%$ & - \\
\hline & Linoleic 15\% & - & - & - & - & - & Diglyceride $7.9 \%$ & - \\
\hline & & & & & & & Monoglyceride & \\
\hline & PaImıtıc 5\% & - & - & - & - & - & $3.1 \%$ & - \\
\hline & Stearic $4 \%$ & - & - & - & - & - & Sterol $0.7 \%$ & - \\
\hline & - & - & - & - & - & - & Tocopherol 0.2\% & - \\
\hline & - & - & - & - & - & - & Phospholipid 3.2\% & - \\
\hline Solvent & trimethylolpropane & xylene & - & - & - & n-hexane & - & xylene \\
\hline Catalyst & Calcium Carbonate & Oxide & $0.1 \% \mathrm{CaO}$ & $\begin{array}{l}\text { lithium } \\
\text { hydroxide; } \\
\text { zirconium octate }\end{array}$ & - & $\begin{array}{l}\text { lead (II) oxide } \\
\text { and xylene }\end{array}$ & - & lead oxide \\
\hline Polybasic acid & phthalic anhydride & $\begin{array}{l}\text { phthalic } \\
\text { anhydride }\end{array}$ & - & $\begin{array}{l}\text { phthalic } \\
\text { anhydride }\end{array}$ & - & - & - & $\begin{array}{l}\text { phthalic } \\
\text { anhydride }\end{array}$ \\
\hline Time & 12 hours & - & 3.5 hours & - & - & - & & - \\
\hline Temperature & $200-250^{\circ} \mathrm{C}$ & $230-250^{\circ} \mathrm{C}$ & $220^{\circ} \mathrm{C}$ & $240-300^{\circ} \mathrm{C}$ & - & - & $225-230^{\circ} \mathrm{C}$ & - \\
\hline Stage & $\begin{array}{l}\text { alcoholysis and } \\
\text { esterification }\end{array}$ & $\begin{array}{l}\text { alcoholysis and } \\
\text { esterification }\end{array}$ & $\begin{array}{l}\text { Part of the oil is carried } \\
\text { out in situ, the } \\
\text { monoglycerides are } \\
\text { deoxidized using a } \\
\text { peracid. Soybean oil } \\
\text { was purified using } \\
\text { performic acid in situ } \\
\text { with benzene as diluent }\end{array}$ & $\begin{array}{l}\text { alcoholysis ( } 290- \\
\left.300^{\circ} \mathrm{C}\right) \text { and } \\
\text { esterification } \\
(240-250 \circ \mathrm{C})\end{array}$ & $\begin{array}{l}\text { alcoholysis and } \\
\text { esterification }\end{array}$ & $\begin{array}{l}\text { In situ } \\
\text { alcoholysis }\end{array}$ & $\begin{array}{l}\text { alcoholysis and } \\
\text { esterification }\end{array}$ & $\begin{array}{l}\text { alcoholysis and } \\
\text { esterification }\end{array}$ \\
\hline
\end{tabular}

Table 1. Alkyd resin from vegetable oil (continued)

\begin{tabular}{|c|c|c|c|c|c|c|c|c|}
\hline \multicolumn{9}{|c|}{ Alkyd resin raw material } \\
\hline Raw & & & & & & & & \\
\hline Material & \multicolumn{2}{|c|}{ Linseed Oil } & \multicolumn{2}{|c|}{ Soybean Oil } & \multicolumn{2}{|c|}{ Rubber Seed Oil } & \multicolumn{2}{|c|}{ Sunflower Seed Oil } \\
\hline Result & $\begin{array}{l}\text { drying time } \\
\text { increased with } \\
\text { increasing oil } \\
\text { content in the } \\
\text { alkyd resin } \\
\text { because the } \\
\text { high oil content } \\
\text { has a low } \\
\text { polymerization } \\
\text { rate of the alkyd } \\
\text { resin }\end{array}$ & $\begin{array}{l}\text { light yellow } \\
\text { with an acid } \\
\text { number of } 1 \\
\mathrm{mg} \mathrm{KOH} \mathrm{/} \mathrm{g,} \\
\text { free fatty acids } \\
0.503 \text {, a } \\
\text { saponification } \\
\text { number of } 194 \\
\text { mg KOH / g, a } \\
\text { drying time of } \\
144 \text { minutes, } \\
\text { an intrinsic } \\
\text { viscosity of } \\
0.0442 \text { [n]. }\end{array}$ & $\begin{array}{l}\text { acid value of } \\
7.045 \\
\mathrm{mgKOH} / \mathrm{g} \text {, } \\
\text { a } \\
\text { saponificatio } \\
\mathrm{n} \text { value of } \\
228,608 \\
\mathrm{mgKOH} / \mathrm{g} \\
\text { an iodine } \\
\text { value of } \\
35.82 \mathrm{Wij}\end{array}$ & $\begin{array}{l}\text { the zirconium } \\
\text { octoate salt } \\
\text { can act as base } \\
\text {-catalyzed } \\
\text { transformation } \\
\text { of triglyceride } \\
\text { by glycerin to } \\
\text { form } \\
\text { monoglyceride } \\
\text { under high } \\
\text { temperature. } \\
\text { The structure } \\
\text { of alkyd resin } \\
\text { was confirmed } \\
\text { by FT-IR and } \\
\mathrm{H}-\mathrm{NMR} \\
\text { spectroscopy } \\
\text { and } \\
\text { comparable } \\
\text { with the alkyd } \\
\text { synthesized } \\
\text { LIOH catalyst }\end{array}$ & $\begin{array}{l}\text { The rubber seed oil } \\
\text { has an iodine value } \\
\text { of } 139.59 \mathrm{~g} \mathrm{I} / 2 \\
100 \mathrm{~g} \text {, a viscosity of } \\
4.905 \mathrm{St} \text {, a free } \\
\text { fatty acid of } 13.87 \\
\mathrm{mg} \mathrm{KOH} \mathrm{/} \mathrm{g} \text { and a } \\
\text { light brown color }\end{array}$ & $\begin{array}{l}\text { the methyl ester of } \\
\text { rubber seed oil has a } \\
\text { specific gravity of } 0.94 \\
\mathrm{~kg} / \mathrm{m} 3 \text {, a refractive } \\
\text { index of } 1.5018 \text {, an acid } \\
\text { value of } 13.80 \mathrm{mg} \mathrm{KOH} \\
/ \mathrm{g} \text {, an iodine value of } \\
71.69 \mathrm{~g} \mathrm{I} / \mathrm{1} / 100 \mathrm{~g} \text { and a } \\
\text { saponification value of } \\
293.02 \text { mg KOH / g. The } \\
\text { acid number of the } \\
\text { alkyd resin depends on } \\
\text { the speed and the } \\
\text { esterification process } \\
\text { while the iodine value } \\
\text { indicates that the } \\
\text { degree of unsaturation } \\
\text { depends on the length } \\
\text { of the oil from the resin. } \\
\text { Based on this, the } \\
\text { rubber seed oil methyl } \\
\text { ester has good } \\
\text { resistance to saltwater, } \\
\text { acids, and water. }\end{array}$ & $\begin{array}{l}\text { Alkyd resin from } \\
\text { SFO has a drying } \\
\text { time of } 225 \\
\text { minutes with an } \\
\text { acid value of } 14.8 \\
\mathrm{mg} \mathrm{KOH} \mathrm{/} \mathrm{g,} \mathrm{a} \\
\text { saponification } \\
\text { value of } 346 \mathrm{mg} \\
\mathrm{KOH} / \mathrm{g} \text {. Based } \\
\text { on these data, it } \\
\text { can be } \\
\text { concluded that } \\
\text { SFO can be used } \\
\text { as a potential } \\
\text { source of raw } \\
\text { materials for the } \\
\text { coating industry }\end{array}$ & $\begin{array}{l}\text { The viscosity of } \\
\text { alkyd resin SFO is } \\
\text { susceptible to } \\
90-180 \text { with a } \\
\text { drying time of } \\
\text { 17-56 minutes, } \\
\text { saponification } \\
\text { value } 188-196 \\
\text { mg } \mathrm{KOH} / \mathrm{g} \text {, } \\
\text { iodine number } \\
136-171, \text { acid } \\
\text { number } 8.13- \\
9.81 \mathrm{mg} \mathrm{KOH} \mathrm{/g}\end{array}$ \\
\hline References & $\begin{array}{c}\text { Işeri-Çaǧlar et al. } \\
\text { (2014) }\end{array}$ & $\begin{array}{l}\text { Godfrey et al. } \\
\text { (2019) }\end{array}$ & $\begin{array}{l}\text { Kyenge et al. } \\
\text { (2012) }\end{array}$ & $\begin{array}{l}\text { Elba et al. } \\
\text { (2018) }\end{array}$ & $\begin{array}{l}\text { Umeobika UC et al. } \\
\qquad(2013)\end{array}$ & $\begin{array}{l}\text { Ikhuoria et al. } \\
\qquad(2007)\end{array}$ & $\begin{array}{l}\text { Chiplunkar and } \\
\text { Pratap (2016) }\end{array}$ & $\begin{array}{c}\text { Mutar and } \\
\text { Hassan (2017) }\end{array}$ \\
\hline
\end{tabular}



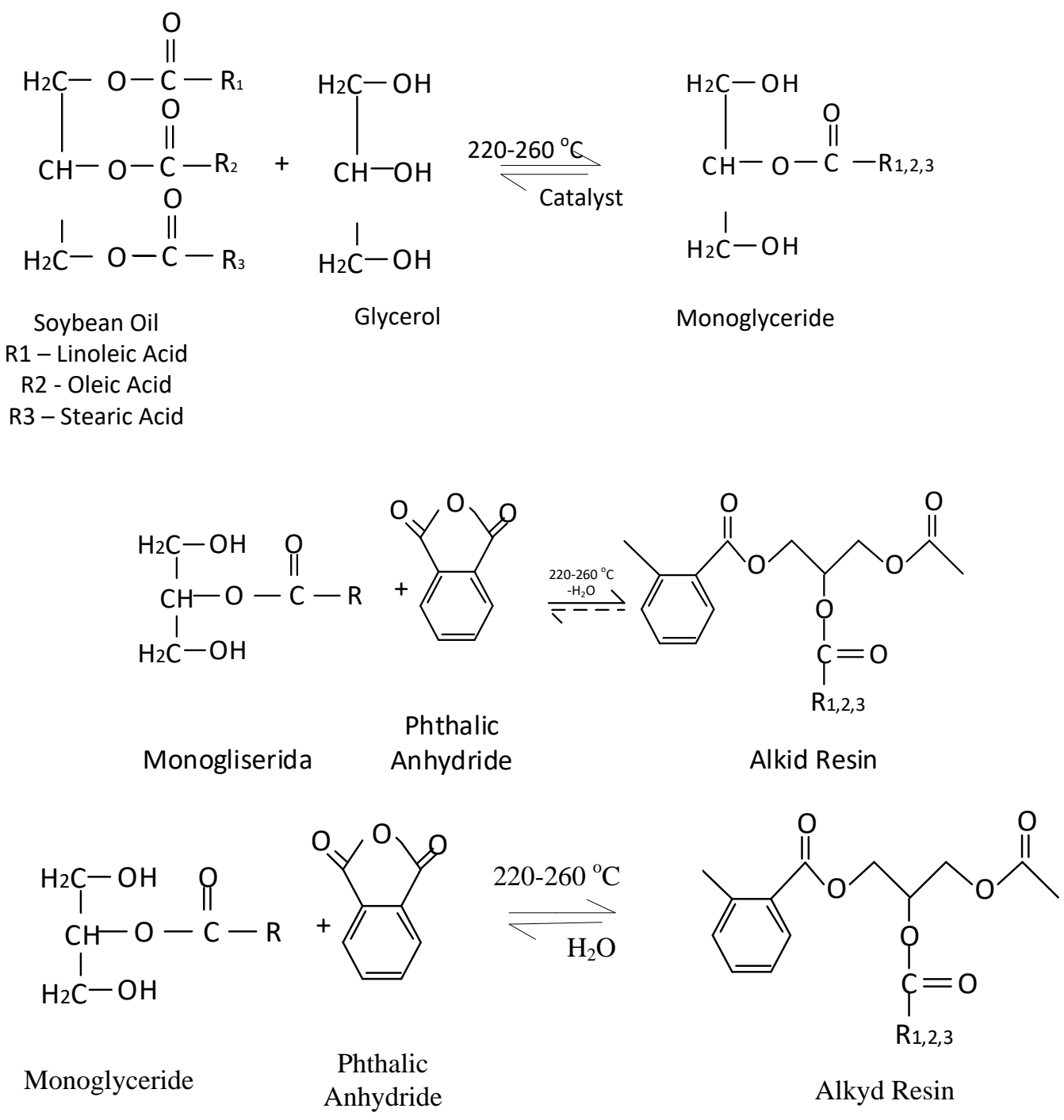

Figure 1. The process of forming a soybean oil alkyd resin. Source: (Soucek and Salata 2014)

Soybean oil used by Kyenge et al. ( 2012) in their experiment has specific gravity of 0.923 , refractive index of 1.4718 , acid value of $0.341 \mathrm{mg} \mathrm{KOH} / \mathrm{g}$, iodine value of $128.4 \mathrm{Wij}$ and saponification value of $189.2 \mathrm{mg} \mathrm{KOH} / \mathrm{g}$. In the study, the effect of alkyd resin modification using soybean oil was compared to the modification using epoxidized soybean oil. Part of the monoglycerides were deoxidized using a peracid that was produced in situ. Soybean oil was purified using performic acid produced in situ with benzene as diluent. Soybean oil, glycerol, and $0.1 \%$
$\mathrm{CaO}$ catalyst were reacted at $220^{\circ} \mathrm{C}$ for 3.5 hours by adding nitrogen which functions as a coolant.. The reaction was stopped when the reaction mixture dissolved in anhydrous methanol with oil to methanol ratio of 1:3. The reaction was cooled to a temperature of $140^{\circ} \mathrm{C}$. After cooling, phthalic anhydride and xylene were introduced to the mixture and the reaction was performed at $230^{\circ} \mathrm{C}$ with nitrogen acting as inert. After the alkyd resin was formed, $5 \%$ zinc was added to accelerate the drying process of the alkyd resin. 
The results showed that the soybean oil modified alkyd resin had an acid value of $7.045 \mathrm{mg} \mathrm{KOH} / \mathrm{g}$, saponification value of $228.608 \mathrm{mg} \mathrm{KOH} / \mathrm{g}$, and iodine value of 35.82 Wij. Meanwhile, epoxidized soybean oil modified alkyd resin had an acid value of 9.35 $\mathrm{mg} \mathrm{KOH} / \mathrm{g}$, saponification value of 260.869 $\mathrm{mg} \mathrm{KOH} / \mathrm{g}$, iodine value of $31.74 \mathrm{Wij}$. The acid value of the epoxidized soybean oil modified alkyd resin was higher than the soybean oil modified alkyd resin, which could be caused by more structural residue due to the epoxidation. The iodine value of the epoxidized soybean oil modified alkyd resin was lower than that of the unepoxidized resin. This was due to the smaller proportion of unsaturated fatty acids due to the epoxidation. The saponification value of the epoxidized oil modified alkyd resin was higher than that of the unepoxidized resin (Kyenge et al., 2012).

Elba et al. (2018) performed alkyd resin synthesis reaction based on soybean oil and glycerin with zirconium octate as catalyst. The alcoholysis reaction of soybean oil and glycerin was carried out in the absence of nitrogen gas inlet, but in the presence of zirconium octate. Soybean oil, glycerin, and lithium hydroxide (as a catalyst) were reacted at the temperature of $290-300^{\circ} \mathrm{C}$, then the reaction was cooled to $180^{\circ} \mathrm{C}$ and after the addition of phthalic acid, the temperature was raised back to $240-250^{\circ} \mathrm{C}$. This process was repeated with zirconium octate as catalyst but the temperature used in the manufacture of monoglycerides was $290-300^{\circ} \mathrm{C}$ and there was no nitrogen gas inlet because the nitrogen gas inlet was only used in the addition of the ophthalmic anhydride step to help remove water from the reaction. Alkyd resin was synthesized using lithium hydroxide and zirconium 2-ethyl hexanoate by alcoholysis process, soybean oil underwent transesterification when heated with glycerol at a temperature of $250^{\circ} \mathrm{C}$. Lithium hydroxide was added as catalyst along with nitrogen inlet to form monoglycerides in the presence of zirconium octate. Soybean oil was transformed into monoglycerides by heating at $290-300^{\circ} \mathrm{C}$ without further oxidation and nitrogen gas inlet, then esterification was carried out by adding ophthalmic anhydride.

Nitrogen gas inlet was used in lithium hydroxide catalyst to prevent oil oxidation. The nitrogen gas inlet was used in the second stage with zirconium octoate with the addition of ophthalmic anhydride which facilitated the removal of water generated during the condensation reaction. The reaction was controlled by measuring the acid value at different time intervals. The reaction was stopped as soon as the desired acid level is reached (Elba et al., 2018). The result showed the zirconium octoate salt can act as base-catalyzed transformation of triglyceride by glycerin to form monoglyceride under high temperature. The structure of alkyd resin was confirmed by FT-IR and H-NMR spectroscopy and comparable with the alkyd synthesized LiOH catalyst.

\subsection{Alkyd Resin from Rubber Seed Oil}

Rubber seed oil is a type of dry oil (drying oil) which can be seen from the high iodine number $139.09 \mathrm{~g} \mathrm{lod} / 100 \mathrm{~g}$ sample. which shows that rubber seed oil is double bonded so that it is easily oxidized to speed up the drying process. The high number of double bonds in rubber seed oil is accounted to the high amount of unsaturated fatty acids that are dominated by linoleic acid (Umeobika UC et al., 2013). The properties of rubber seed oil 
correspond to alkyd resin products which can be applied as a coating. Alkyd resin seed oil with equivalent ratio $\left(R_{e k}\right)=1.3$ has an acid number of $7.6068 \mathrm{mg} \mathrm{KOH} / \mathrm{g}$ sample, viscosity $1.1203 \times 10^{-2}$ poise (Nurandini et al., 2018).

To improve the quality of the alkyd resin of the rubber seed oil methyl ester, Ikhuoria et al. (2007) performed in situ alcoholic process of rubber seeds to obtain the rubber seed oil methyl ester. The catalysts used are lead (II) oxide and xylene. In situ alcoholysis of rubber seed oil methyl ester was carried out by maceration using methanol for 30 minutes and stirred for 3 hours at room temperature,

Stage 1. Alcoholysis

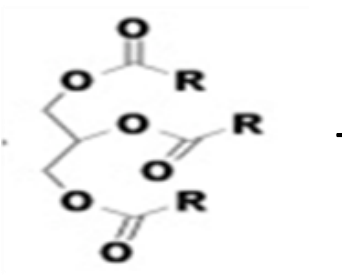

RSO

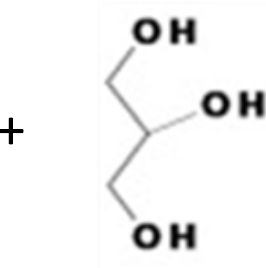

Glycerol

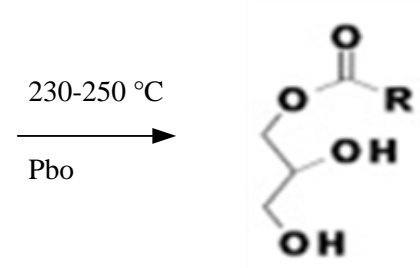

RSO monoglyceride

\section{Stage 2. Esterification}

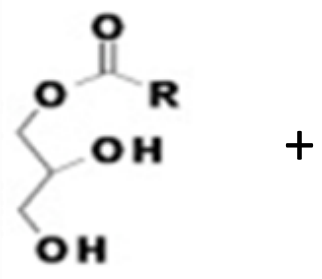

RSO monoglyceride

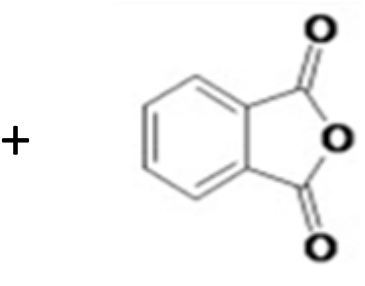

Phtalic anhydride

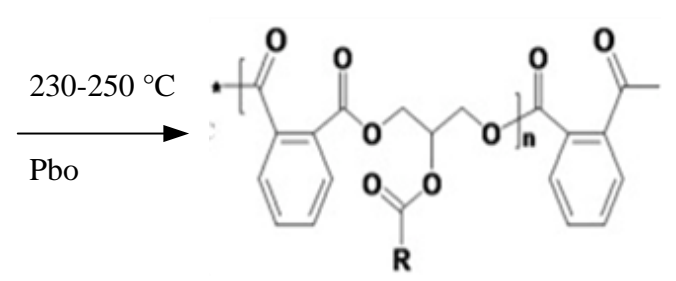

Alkyd Resin

Stage 1. Alcoholysis

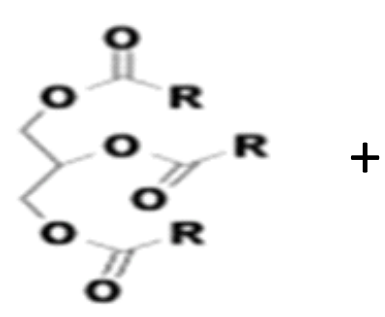

RSO

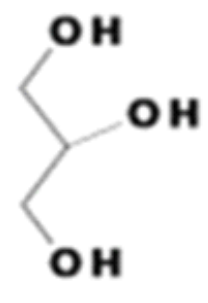

Glycerol

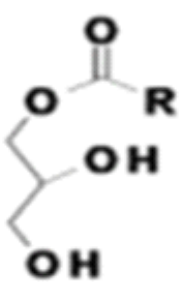

RSO monoglyceride

Stage 2. Esterification

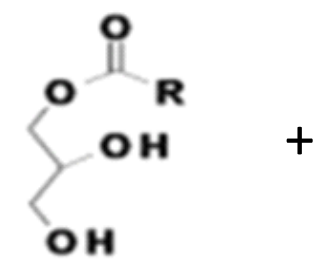

RSO monoglyceride<smiles>O=C1OC(=O)c2ccccc21</smiles>

Phthalic Anhydride

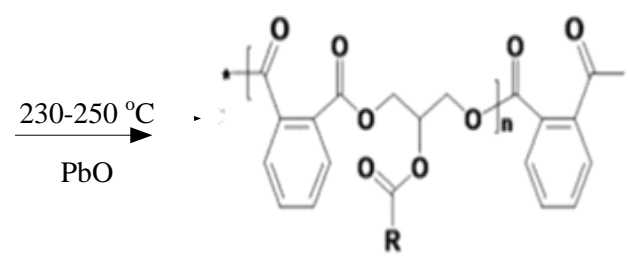

Alkyd Resin

Figure 3. The process of forming a rubber seed oil alkyd resin. Source: (Godfrey et al., 2019) 
then vacuum filtered, and the remaining residue was washed with $200 \mathrm{ml}$ of methanol. The residue obtained was extracted with nhexane using Soxhlet filtrate obtained from in situ alcoholysis, added with $100 \mathrm{ml}$ of water and the solution was re-extracted with $50 \mathrm{ml}$ of $n$-hexane three times. The alkyd resin making process was carried out in 2 steps, namely alcoholysis and esterification.

Based on the experiment result, Ikhuoria et al. (2007) mentioned that the methyl ester of rubber seed oil had a specific gravity of 0.94 $\mathrm{kg} / \mathrm{m}^{3}$, a refractive index of 1.502 , an acid value of $13.80 \mathrm{mg} \mathrm{KOH} \mathrm{/} \mathrm{g}$, an iodine value of $71.69 \mathrm{~g} \mathrm{I}_{2} / 100 \mathrm{~g}$ and a saponification value of $293.02 \mathrm{mg} \mathrm{KOH} / \mathrm{g}$. The acid number of the alkyd resin depends on the speed and the esterification process while the iodine value indicates that the degree of unsaturation depends on the length of the oil from the resin. Based on this, the rubber seed oil methyl ester has good resistance to saltwater, acids, and water.

Umeobika UC et al. (2013), synthesized rubber seed oil using an oil length of 35\% for short alkyd and $50 \%$ for medium alkyd using the alcoholysis method. The rubber seed oil has an iodine value of $139.59 \mathrm{~g} \mathrm{I}_{2} / 100 \mathrm{~g}$, a viscosity of $4.905 \mathrm{St}$, a free fatty acid of 13.87 $\mathrm{mg} \mathrm{KOH} / \mathrm{g}$ and a light brown color. These results indicated that rubber seed oil is eligible for use in the production of alkyd resins, has comparable coating properties to commercial alkyd resins such as air-dried films and exhibits good chemical resistance in various solvent media such as brine and water. The short and medium alkyd resin iodine values were $30.90 \mathrm{~g} \mathrm{I}_{2} / 100 \mathrm{~g}$ and 42.50 $\mathrm{g} \mathrm{I}_{2} / 100 \mathrm{~g}$, respectively, indicating that the level of alkyd resin unsaturation increased with the proportion of rubber seed oil used in production.

\subsection{Alkyd Resin from Sunflower Seeds}

Sunflower acid oil (SFO) is a by-product of refining vegetable oil which consists of free fatty acids with a small amount of glycerol and sterols. Sunflower oil contains long-chain unsaturated fats such as oleic acid. SFO is used to modify alkyd resins and obtain hydroxylated polyester derivatives (Selim et al., 2017).

Sunflower acid oil contains free fatty acids $(65 \%, w / w)$ with triglycerides $(15.5 \%, w / w)$, diglycerides $(7.9 \%, w / w)$, monoglycerides $(3.1 \%, w / w)$, sterols $(0.7 \%, w / w)$, tocopherol $(0.2 \%, w / w)$, and phospholipids $(3.2 \%, w / w)$. Alkyd resin from SFO has a drying time of 225 minutes with an acid value of $14.8 \mathrm{mg} \mathrm{KOH} /$ $\mathrm{g}$, a saponification value of $346 \mathrm{mg} \mathrm{KOH} \mathrm{/} \mathrm{g.}$ Based on these data, it can be concluded that SFO can be used as a potential source of raw materials for the coating industry (Chiplunkar and Pratap, 2016).

The alkyd resin based on sunflower oil is synthesized in two stages. The first stage is to convert sunflower oil or linoleic acid into monoglycerides as polyols by alcoholysis. The esterification process takes place in the second stage by adding phthalic anhydride and xylene. The synthesis process is carried out with the help of catalyst lead oxide. The viscosity of alkyd resin SFO is susceptible to 90-180 with a drying time of 17-56 minutes, saponification value of $188-196 \mathrm{mg} \mathrm{KOH} / \mathrm{g}$, iodine number of $136-171$, and acid number of 8.13-9.81 mg KOH/g (Mutar and Hassan, 2017). 
3. The Superiority of Alkyd Resins from industry today is to replace synthetic

\section{Vegetable Oils}

Alkyd resin is a polymer product that is widely used in the paint and coating industry.Alkyd resins are obtained through a polyesterification process, which is a reaction to make polymers using condensation that combines carboxyl and hydroxyl groups (Stevens, 2001). Polymers from natural materials have undergone some developments. The challenge for the bio- materials with natural, environmentally friendly materials. Natural materials used at least need to resemble synthetic materials that have low costs and high quality materials as commodity polymers (Lligadas et al., 2013). The natural ingredient for forming alkyd resins is vegetable oil.

Vegetable oil is a potential and abundant renewable biological resource. Vegetable oil triglycerides have an important role in polymer synthesis.

Stage 1. Alcoholysis

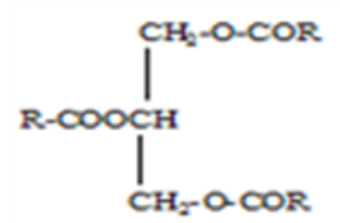

Sunflower Oil

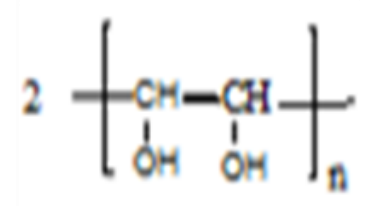

Polyethylene glycol

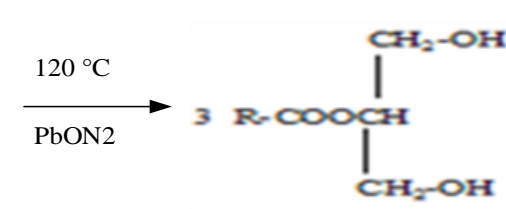

Monoglyceride

Stage 2. Esterification

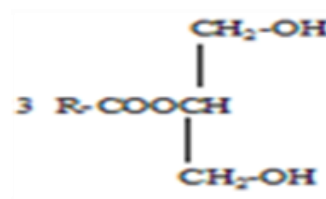

Monoglyceride

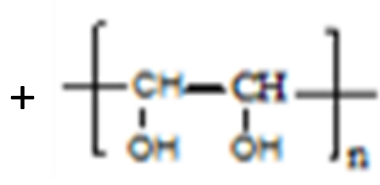

Polyethylene glycol

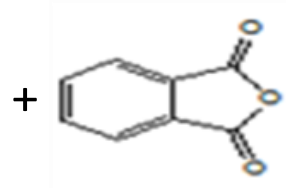

Phtalic anhydride
$240{ }^{\circ} \mathrm{C}$

PbON2
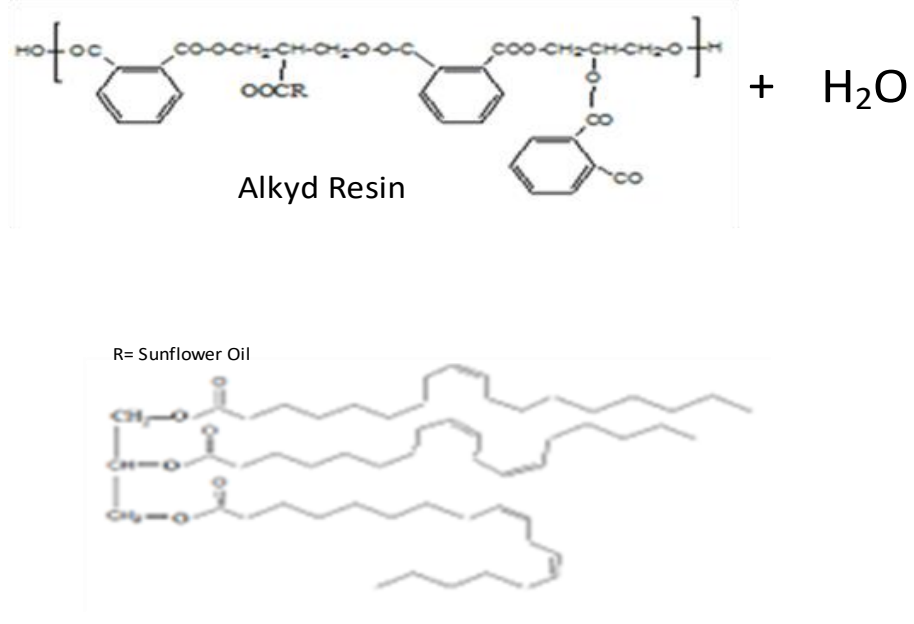
Stage 1. Alcoholysis<smiles>[R]OCC(CC([R])OC([R])=O)C([R])=O</smiles>

Sunflower Oil<smiles>CC(C)(C)C(O)C(C)(C)C</smiles>

Polyethylene glycol

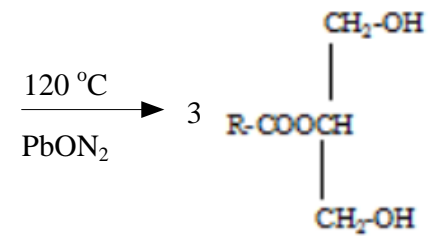

Monoglyceride

Stage 2. Esterification<smiles>[R]OC(=O)CO</smiles>

$+$<smiles>CC(C)(C)C(O)C(O)C(C)(C)C</smiles><smiles>O=C1OC(=O)c2ccccc21</smiles>

$240{ }^{\circ} \mathrm{C}$
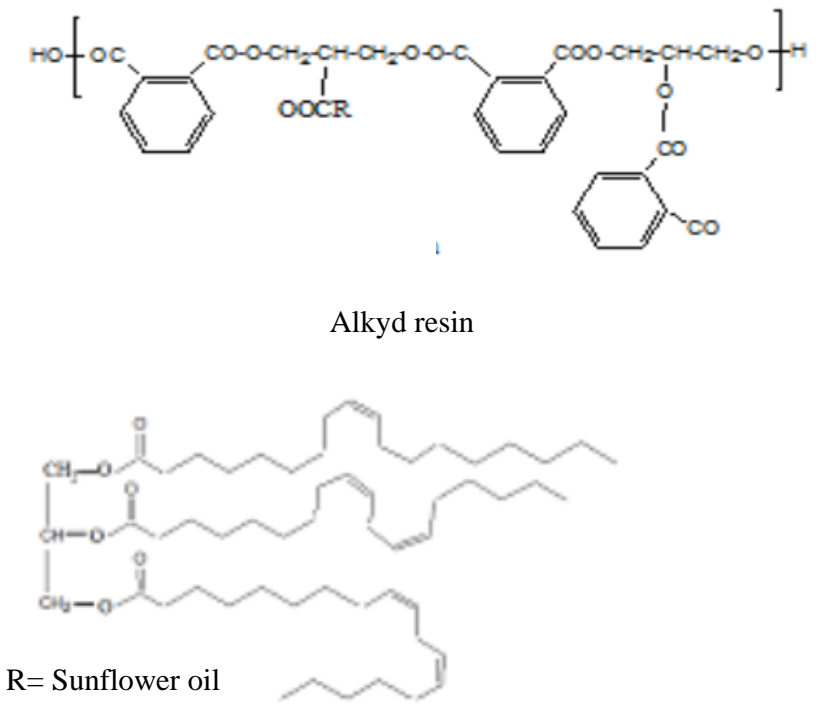

Figure 4. The process of forming sunflower seed alkyd resin. Source: (Mutar and Hassan 2017).

The use of vegetable oils in the alkyd resin industry is as a drying agent. Oils that are suitable for drying are the highly unsaturated ones that will undergo oligomerization or polymerization when exposed to oxygen in the air, generally with the addition of a catalyst. (Derksen et al., 1996). Alkyd resins from vegetable oils have been the focus of many research to develop. The production of alkyd resins with vegetable materials has met the eco-friendly aspect because without the formation of chemical by-products, waste can be processed, and the exploitation of nonrenewable resources can be avoided. So, in principle, oil production has proven to be 
technologically feasible and able to replace fossil raw materials (Lligadas et al., 2013).

The structure of alkyd resin is about 60$70 \%$ of the derivative or degradable raw materials (fatty acids, glycerol, pentaerythritol) and non-biodegradable (phthalic acid) (Hofland, 2012). Alkyds are divided into two, namely dry alkyd and nondrying alkyd which refers to the drying properties of vegetable oils. Vegetable oils exhibit good gloss retention, durability, and weathering poor chemical resistance, particularly in alkaline media due to the presence of higher amounts of esters (Dutta et al., 2006; Haseebuddin et al., 2009; Hofland, 2012).

\section{Future Perspective}

Vegetable oils are readily available, costeffective, and environmentally friendly. Published studies showed that natural materials have the potential for biodegradation as environmentally friendly renewable materials. The use of vegetable oil as a coating material has been carried out during the last few periods. Nowadays, the development of research on the modification of materials to make products that are environmentally friendly with efficient costs continues to be carried out.

Alkyd resin production processes require high temperature, long time and large amount of solvents. Long drying times and high drying temperatures can reduce quality. Therefore, optimization is needed to minimize the use of solvents during extraction and the production cost. Vegetable oils utilization for alkyd resins need to be adapted for specific uses according to the commercial alkyd resins commonly used by the paint industry.
The paint industry's need for alkyd resin and environmentally friendly products have led to the need to develop raw materials from vegetables that are effective and incongruent to the need of food industry. So far, vegetable oils used in the alkyd resin industry are also produced for the food industry, so that alternatives to other vegetable materials that have abundant availability are needed.

Alkyd resin synthesis process from vegetable oil can be done using polymer technology. The polymer technology used in the process of making alkyd resins goes through 2 stages, namely alcoholysis and esterification. The alcoholysis step is carried out by adding a catalyst to shorten the reaction time. The catalyst can identify the biodegradation of vegetable oil polymers. The esterification step is carried out by adding phthalic acid to form alkyd resins at high temperatures. Based on the manufacturing stage, it requires a fairly long time and relatively high costs. So, it is necessary to analyze the process stages in situ to streamline the process of making alkyd resins. Another approach to the alkyd resin development process could be to use drying or non-drying oil in layers as paint.

In situ transesterification or alcoholysis are a technology for the oil extraction process and the esterification or transesterification reaction which is carried out simultaneously where the oil extraction process and the esterification or transesterification reaction are carried out in one reactor. (Haas et al., 2004). The in situ process begins with the contact between the alcohol and an acid or alkaline catalyst. Then the alcohol enters the cell and destroys the parts of the cell and then dissolves the oil contained in the raw material. The extracted oil reacts with alcohol to 
produce alkyl esters with the help of an acid or base catalyst. So that the production process can shorten production time, be efficient, save energy and produce high quality biodiesel (El-Enin et al., 2013).

\section{Conclusions}

Vegetable oils are abundant and environmentally friendly, so they are suitable to be used as raw material for alkyd resins. Vegetable oils can generally be used as raw material for polymers because they contain lots of triglycerides, drying oil and non-drying oil. To streamline the process of making alkyd resin, it is necessary to study the raw materials that are not used simultaneously with the food industry, technology and catalysts used which can refer to industries that are environmentally friendly and affordable.

\section{References}

Aigbodion, A.I. and Okieimen, F.E., 2001, An investigation of the utilisation of African locustbean seed oil in the preparation of alkyd resins, Ind. Crops Prod., 13 (1), 29-34. Alam, M., Akram, D., Sharmin, E., Zafar, F. and Ahmad, S., 2014, Vegetable oil based ecofriendly coating materials: A review article, Arab. J. Chem., King Saud University, 7 (4), 469-479.

Anya, A., Jack, I. and Osagie, O., 2016, Synthesis and characterization of oilmodified alkyd resin from epoxidized neem oil, Am. Chem. Sci. J., 15 (2), 1-7.

Chiplunkar, P.P. and Pratap, A.P., 2016, Utilization of sunflower acid oil for synthesis of alkyd resin, Prog. Org. Coatings, Elsevier B.V., 93, 61-67.

Derksen, J.T.P., Cuperus, F.P. and Kolster, P., 1996, Renewable resources in coatings technology: A review, Prog. Org. Coatings, 27 (1-4), 45-53.

Dutta, Karak and Dolui., 2006, Alkyd-epoxy blends as multipurpose coatings, Apll. Polym. Sci., 100, 516-521.

El-Enin, A., Attia, N., El-Ibiari, N., El-Diwani, G. and El-Khatib, K., 2013, In situ transesterification of rapeseed and cost indicators., Renew. Sustain. Energy Rev., 18, 471-477.

Elba, M.E., Abdel Rehim, E.M. and Ashery, R.E., 2018, Synthesis and characterization of alkyd resin based on soybean oil and glycerin using zirconium octoate as catalyst, Int. J. Chem. Technol., 2 (1), 34-43. Godfrey, O.O., Ifijen, I.H., Mohammed, F.U., Aigbodion, A.I. and Ikhuoria, E.U., 2019, Alkyd resin from rubber seed oil/linseed oil blend: A comparative study of the physiochemical properties, Heliyon, 5 (5), $0-4$.

Haas, M., Scott, K., Marmer, W. and Foglia, T., 2004, In situ alkaline transesterification : an effective method for the production of fatty acids esters from vegetable oils, JAOCS, 81 (1), 83-89.

Haseebuddin, S., Parmar, R., Waghoo, G. and Ghosh, S.K., 2009, Study of hexafunctional polyol in high solids air-drying alkyd: improved film performance, Prog. Org. Coat., 64, 446-453.

Hofland, A., 2012, Alkyd resins: from down and out to alive and kicking., Prog. Org. Coat., 73, 274-282.

Ikhuoria, E.U., Aigbodion, A.I. and Okieimen, F.E., 2007, Enhancing the quality of alkyd resins using methyl esters of rubber seed oil, Trop. J. Pharm. Res., 3 (1), 311-316.

Işeri-Çağlar, D., Baştürk, E., Oktay, B. and Kahraman, M.V., 2014, Preparation and 
evaluation of linseed oil based alkyd paints, Prog. Org. Coatings, 77 (1), 81-86. Islam, M.R., Beg, M.D.H. and Jamari, S.S., 2014, Development of vegetable-oil-based polymers, J. Appl. Polym. Sci., 131 (18), 9016-9028.

Kildiran, G., Yücel, S.Ö. and Türkay, S., 1996, In situ alcoholysis of soybean oil , J. Am. Oil Chem. Soc., 73 (2), 225-228.

Kyenge, B. a, Anhwange, B. a, Ageh, J.T. and Igbum, G.O., 2012, Comparative analysis of soybean seed oil modified alkyd resin and epoxidized soybean seed oil modified alkyd resin, Int. J. Mod. Org. Chem., 1 (2), 66-71.

Lligadas, G., Ronda, J.C., Galià, M. and Cádiz, V., 2013, Renewable polymeric materials from vegetable oils: A perspective, Mater. Today, 16 (9), 337-343.

Mutar, M.A. and Hassan, N.M.A., 2017, Synthesis and characterization of new alkyd resins ( short, medium and long ) based on sunflower oil and linoleic acid as ( short, medium and long ) based on sunflower oil and linoleic acid as binder for paints, J. Chem. Petrochemical Technol., 7 (February), 1-16.

Nurandini, D., Rochmadi and Murachman, B., 2018, Karakterisasi alkyd resin dari gliserol dan asam adipat yang dimodifikasi dengan minyak biji karet sebagai komponen surface coating yang ramah lingkungan, J. GEOSAPTA, 4 (2), 139-142.

Ploeger, R. and Chiantore, O., 2012, Characterization and stability issues of artists ' alkyd paints, Smithson. Contrib. to Museum Conserv., 3 (November 2010), 89 95.

Salimon, J., Salih, N. and Yousif, E., 2012, Industrial development and applications of plant oils and their biobased oleochemicals, Arab. J. Chem., King Saud University, 5 (2), 135-145.

Selim, M.S., Shenashen, M.A., Elmarakbi, A., Saeed, A.M.E.-, Selimd, M.M. and El-Safty, S.A., 2017, Sunflower oil-based hyperbranched alkyd/spherical ZnO nanocomposite modeling for mechanical and anticorrosive applications, R. Soc. Chem., 7, 21796-21808.

Soucek, M.D. and Salata, R.R., 2014, Alkyd Resin Synthesis, Encycl. Polym. Nanomater., pp. 6-11.

Sutanti, S., Purnavita, S., Sriyana, H.Y. and Pembahasan, H., 2013, Pemanfaatan minyak biji rami (linseed oil) dan gliserol by-product biodiesel, Media Komun. Rekayasa Proses dan Teknol. Tepat Guna, 9 (1), 8-14.

Umeobika UC, Onuegbu TU, lloamaeke MI and Ekwueme IJ., 2013, Synthesis and evaluation of performance characteristics of rubber seed oil-modified short and medium alkyd resins, Int. J. Sci. Innov. Discov., 3 (1), 86-92.

Uzoh, C.F. and Nwabanne, J.T., 2016, Investigating the effect of catalyst type and concentration on the functional group conversion in castor seed oil alkyd resin production, Adv. Chem. Eng. Sci., 06 (02), 190-200.

Wibowo, H.B., 2013, Karakterisasi dan pengujian resin polyalkyd alami sebagai elastomer, Chem. Prog, 6 (1), 1-5.

Winarsi, D.., 2010, Protein Kedelai dan Kecambah, Kanisius, Yogyakarta.

Xia, Y. and Larock, R.C., 2010, Vegetable oilbased polymeric materials: Synthesis, properties, and applications, Green Chem., 12 (11), 1893-1909 